\title{
Science Fiction in Digital Media
}

\section{Rosnidar Ain}

To Link this Article: http://dx.doi.org/10.6007/IJARBSS/v11-i11/10964

DOI:10.6007/IJARBSS/v11-i11/10964

Received: 06 September 2021, Revised: 09 October 2021, Accepted: 27 October 2021

Published Online: 11 November 2021

In-Text Citation: (Ain, 2021)

To Cite this Article: Ain, R. (2021). Science Fiction in Digital Media. International Journal of Academic Research in Business and Social Sciences, 11(11), 1522-1533.

Copyright: ( 2021 The Author(s)

Published by Human Resource Management Academic Research Society (www.hrmars.com)

This article is published under the Creative Commons Attribution (CC BY 4.0) license. Anyone may reproduce, distribute, translate and create derivative works of this article (for both commercial and non0-commercial purposes), subject to full attribution to the original publication and authors. The full terms of this license may be seen

at: http://creativecommons.org/licences/by/4.0/legalcode

Vol. 11, No. 11, 2021, Pg. $1522-1533$

http://hrmars.com/index.php/pages/detail/IJARBSS

JOURNAL HOMEPAGE

Full Terms \& Conditions of access and use can be found at http://hrmars.com/index.php/pages/detail/publication-ethics 


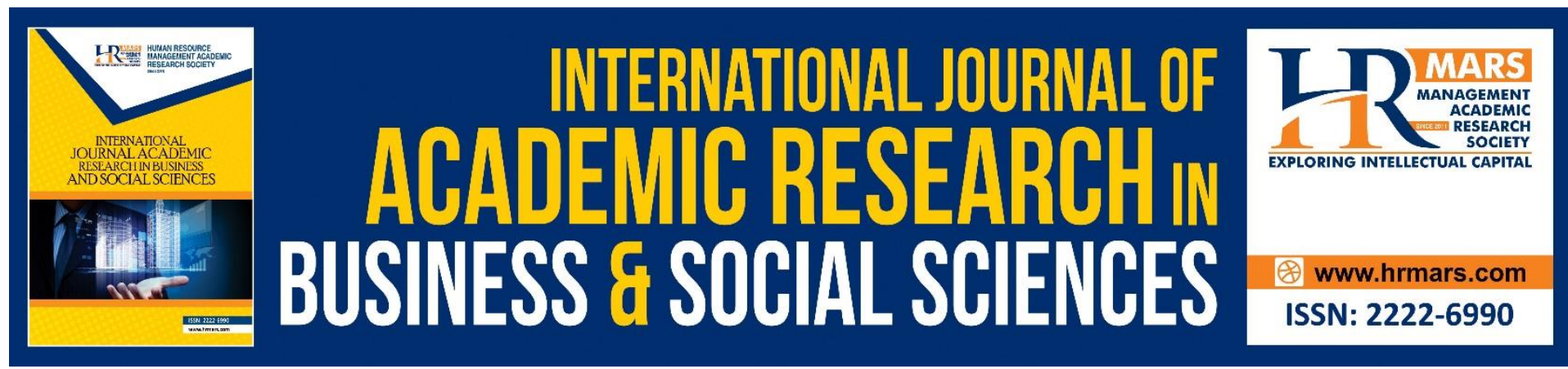

\title{
Science Fiction in Digital Media
}

\author{
Rosnidar Ain \\ School of Humanities, Universiti Sains Malaysia, 11800, Pulau Pinang \\ Email: rosnidar_ain@usm.my
}

\begin{abstract}
Science Fiction is one of the literary genres that has not been given much attention in Malaysian research, especially when it concerns its presence in digital world. Publication of science fiction novels in the form of printed materials is multiplying in the book market. Authors have begun to show more interests in producing science fiction novels since they are gaining more demand among literary enthusiasts. Hence, this study aims to focus on science fiction literary materials which exist in the digital media. Since there is a limited number of studies on science fiction especially the one online, this research aims to unravel science fiction digital texts. The focus is not limited to only Malay science fiction, but it covers materials from the Western authors too. In addition, as the goal of study, this research would like to emphasize on science fiction written materials from both medium while giving focus on their form and creativity. The methodology of this research will involve three section such as contextual analysis, content analysis and observation. Three digital media namely Youtube, social media and websites are the focus of digital platforms to be studied. Through this research, it is apparent that Malay science fiction is still left behind in terms of its form and content even though attempts to expand this genre is rather successful.
\end{abstract}

Keywords: Science Fiction, Digital Media, Youtube, Social Media, Innovation.

\section{Introduction}

Science fiction narratives which were slowly progressing compared to other genres, are now beginning to gain attention among authors and readers. This phenomenon stems from the growing number of blockbuster science fiction films such as Star Wars, The Maze Runner, The Hunger Games, The Martian, Passenger and the list goes on. In the past, films such as Back to The Future, The Time Machine and the others were the proponent of this genre. As more science fiction novels are published and some make their way into movie adaptations, the public's acceptance of science fiction as a genre is beginning to gain its positive momentum.

How does one define science fiction?

Larousse (Aydin et al., 2006), defined science fiction as "a type of literature and cinema that takes place in the fictional extend-times (especially in future times), create societies and living animates and in that sense, it mentions sciences, techniques and conditions, totally different from the ones in our time". In fact, no consensus has been obtained when it comes to the exact meaning of science fiction. Roberts said, science fiction is a complex literary genre that resists easy definitions (Shahizah et al., 2010). Some of the definitions include fantasy as one 
of the characteristics of science fiction. Others believe that science fiction can be defined through categories. Robert A. Heinlen stated that, science fiction is a realistic speculation towards the possibilities in the future, based on knowledge or the past reality or the present with an understanding of nature and significant scientific methods (Basset et al., 2013). However, Evnine (2015) provides an explanation of science fiction by describing Suvin's statement;

Suffice it to say that the estrangement of which he speaks is that associated with the novum-works of science fiction, by definition, according to Suvin, involve something that is not to be found in our current circumstances, be it life on other planets, interaction with alien beings, time travel, or other such staples of the genre. To distinguish science fiction from fantasy, however, Suvin requires that the novum be treated as a natural rather than super- natural phenomenon, hence validated by what he calls cognition or cognitive logic. (Pg, 11)

Kingsley Amis in GMP Kumari (2013) explained that science fiction is a narrative about situations that do not occur from the world that we know: it also contains a hypothesis about innovation and technology, or futuristic technology introduced by either humans or nonhumans. Generally, science fiction is a vast genre that is related to the future or an imaginative space: it involves speculations on current scientific facts, designs or creations can be visualized as they offer possibilities or exploration towards new discovery based on facts and scientific thinking. In other words, science fiction materials must bring forth innovations related to science and technology which are attainable or ideas that offer knowledge based on science and technology to the readers.

Malaysian science fiction has witnessed a sluggish development compared to the others and considered 'young' in this country (Azah \& Yosman, 2010). They were produced in the 70s mainly by Othman Puteh and Nazel Hashim Mohamad. Then, science fiction reading materials were published by Dewan Bahasa dan Pustaka through Ghazali Ngah Azia and Rubaidin Siwar as well-known authors of this genre. However, the popularity of science fiction was short lived as it did not get much attention in 70s and 80s. In the 90s, science fiction suddenly made a comeback when Dewan Bahasa dan Pustaka trained and provided opportunities for young authors from Minggu Penulis Remaja (MPR) program. Well known authors of that era were Hizairi Othman, Ahmad Patria Abdullah, Nisah Haron, Uthaya Sankar, Sharkawi Che Din, Shaharil Hasrin Sanin and several other. Until today, science fiction literary materials have gone through positive development and this genre has won the hearts of many authors and readers. Twentieth century was the era in which science fiction authors were active due to the introduction of digital media and Indie publication companies. Rahmat Haroun was chosen as the Father of Malaysian science fiction with his writing entitled Di.Ar.Ti, Panggil Aku Melaju, Manuklon and others due to his prolific ways. Authors who wrote in this era, other than Rahmat Harun, were Ediramle Ismail, Fadli Al-Akiti, Nazel Hashim Mohamad and a few others.

Looking at science fiction genre in the digital world, there is an apparent weakness in comparison to other literary materials. Authors focus mostly on printed publication as the opposite of online publication in the digital realm. This is indicative of their dependency on the publisher which has not changed, and suffice to say, authors are not ready to leave their comfort zone, maximizing the advantage of using text. In this article, studies on literary text 
in the digital space as well as the elements of cyber literature applied will be given the emphasis.

\section{Research Objectives}

- To clasify science fiction in digital media

- To analyse science fiction in digital media

\section{Problem Statement}

Literature contains many genres in relation to fiction writing as it can be divided into several categories such as romance, thriller, fantasy, horror, mystery, science fiction and others. Nevertheless, research on science fiction as a genre is seldom brought forward while comparatively, science fiction is gaining strong footing in Malaysian literary scene. The presence of science fiction in this country can easily be searched through digital media as it is getting more popular among the youngsters be it the authors or readers of this age group. Since there is a limited number of studies on science fiction especially the one online, this research aims to unravel science fiction digital texts. Most researches focus on science fiction texts in the physical form and very little exploration is made into the potential of digital space or the Internet to write. Because physical books are easier to sell, many readers give less attention to online texts.

\section{Research Questions}

In order to achieve the research objective, several main questions have been developed. These questions are formed to give focus on the research that is going to be conducted. Comparison between intrinsic and extrinsic nature of science fiction in conventional media could be studied through the research questions formed. However, through digital media, the research questions developed are in the form of basics since this study is still in its infancy in order to identify literature in digital space. Some issues that need to be addressed are what is the form of science fiction in digital media? Next, does the form remain the same with conventional text or has it conformed to the digital literature standard? This research also aims to uncover online science fiction texts in digital media and their authors. Lastly, it is also the objective of this research to find out the reason behind the need to study science fiction texts in the digital space. Therefore, all of these research questions must be answered in order to achieve the objectives determined.

\section{Purpose of The Study}

Findings of this research will contribute to the growth of knowledge in science fiction especially those which are available in the digital space. This research is able to benefit the literary field particularly to researchers or readers who are interested in science fiction genre - digital media offers a space for texts to be published online. Studies through digital are limited since many researchers are more inclined to analyze a text based on several theories. However, this study explores more into the knowledge derived from texts in the cyber real. It is hoped that the findings will give an impact and lead to in depth research in the same genre.

\section{Literature Review}

Local researchers do not pay enough attention to the study of science fiction in digital media. Most research are directed towards studies on existing science fiction texts or texts in the 
form of novels. For science fiction in digital media, most research come from foreign researchers.

One of the relevant studies in this field comes from Thomas Haigh (2011) entitled 'Technology's Other Storytellers: Science Fiction as History of Technology' as published in Science Fiction and Computing: Essays on Interlinked Domains. Nevertheless, this research focused more on history and technology of science fiction which was not inclusive of specific use of media as compared to the current study. Another research was conducted by Thomas and John (2013) as featured in 3D, SF, and the Future. It attempted to work on a prototype in applying 3D to printing device which was produced based on ideas derived from several science fiction texts. In The Essential Science Fiction Television Reader edited by Telotte (2008), the author discussed science fiction in media, but it emphasized more on television programmes. Discussion in this article revolved around science fiction television shows and narrative that were aired. Others discussed the fan culture and future of science fiction on television. Most of these articles do not provide discussion on science fiction in digital media particularly those in the new media.

Basically, studies on science fiction and its relation to technology are related to discussion on emerging technologies inspired by science fiction. For instance, Jan Pater wrote 'Impact of Science Fiction Literature on Science and Technology: Future Challenges of Informatics'; in which an article by Caroline, Ed and George (2003) entitled Better Made Up: The Mutual Influence of Science Fiction and Innovation was published as well as an article by Torras (2020) namely Science-Fiction: A Mirror for the Future Mankind. In fact, there are numerous articles on science fiction and technology but they do not specifically deal with science fictions texts in the latest digital media platforms such as Youtube, applications and others.

\section{Research Methods}

This study employs the qualitative method that analyzes a written source of science fiction works which are available in the electronic media especially the internet. In order to obtain information needed, this study used three basic method that involved contextual analysis, content analysis and observation.

\section{Contextual Analysis}

Contextual analysis process in this research was focused on finding the principles, characteristics, components and guidelines which were of often mentioned or discussed by experts whose source taken from books, journals or articles from local or abroad. In order to obtain information from previous research, comparison was made by looking at novels which could be accessed from the internet.

\section{Content Analysis}

Content analysis is based on comparisons made between texts, for instance between online and conventional works.

\section{Observation}

This study will use observations as the method of the research. Observation was done by browsing through some websites, social media and digital medium which provide the science fiction works on the Internet. Through this research method, several types of science fiction work, which had multimedia features or not were identified. 


\section{Analysis, Discussion and Findings}

Ahmad Zaki stated that, science and technology fiction novels are not just flying saucers, space adventures, aliens, and robots only, it is actually more to a combination of exploring in the realm of mystery fiction, action, fantasy, detective and technology (Rosnani et al., 2021). In Malaysia, more authors are interested to write this genre. Some well-known authors are Ahmad Patria Abdullah, Rahmat Haroun, Fadli Al-Akiti, Nazel Hashim Mohamad and many others. However, these authors are more comfortable in publishing their work through conventional publication. They utilize digital medium to create followers, share and promote their work. Science fiction texts like other genres, have stepped into the new media and technology era. In digital space, science fiction texts can be accessed through websites or social media sites. Some websites enable readers to directly read from them without having to download the texts prior to that.

\section{Science Fiction through Social Media}

According to Edosomwan, social media plays and important role in transforming information and making it easier to communicate with others (Murad et al., 2018). Social media is also becoming a potential space to expand science fiction. Based on observation, through the focus given on Facebook as the most common social media site, most pages are created to feature materials such as films, novels and discussions concerning science fiction. When searched under the keyword science fiction, some pages would emerge such as Science Fiction, ScienceFiction.com, Science Fiction and Fantasy Authors, Science Fiction Book Club, All Thing Science Fiction and several others. Apart from using the science fiction as a keyword, Sci-Fi search led to different pages such as Sci-Fi, Sci-Fi Visions, Scifi Imaginarium, SciFi and others. The pages do not allow the authors to write but they provide information on this genre. Another search using the keyword Science Fiction Short Story revealed pages such as Fiction Writers and Readers which are suitable for this research. This page enables authors to upload their work, readers can go through and these texts are later linked to the websites, blog or author's written medium. One example of this is Steve Car with his work entitled The Sinking of The Jade Rabbit (2019).

To search for science fiction in Malay, the search was made using keywords Sains Fiksyen and several pages were discovered. Some pages only provide information, texts related to the genre: some come together online to share opinion and others use the platform to do promotion. Some of these pages are Sains Fiksyen, Sayembara Novel Fiksyen Sains and Teknologi UTM-Kumpulan Utusan dan Teknologi and Fiksyen Shasha. Fiksyen Shasha is interesting since it enables the authors to post their work and the chosen ones will be featured on fiksyenshasha.com as well as published in the form of printed book. Nevertheless, texts which are found at Fiksyen Shasha page are more inclined to horror and fantasy as compared to science fiction. In addition, Facebook Gempak Starz also features science fictions texts in the form of novel and comic. Gempak Starz has its own website namely GEMPAKSTARZ.Store.

\section{Science Fiction on Websites}

Most authors prefer to use websites or blogs to write. Blog writings are easier to find since blog is able to keep many texts and it is more user-friendly compared to Facebook: the latter requires readers to scroll the written status one by one. Hence, Facebook is used as a means of promotion or to provide information to the readers or users about the texts which have been written. Based on observation, the presence of science fiction is stronger in this space. 
One example is Daily Science Fiction which features scientific based fictions. Under the topic of Science Fiction, there are several sub-topics to ease readers to choose the texts that they are interested in. The website also invites readers or authors to share their texts. One of the highest ranked text is Quantum Mechanics by Anatoly Belilovsky.

Other websites which feature science fiction texts are Bookriot.com that gives links or network to other websites such science fiction magazines or short stories based on the genre. Links which are available on this website are Lightspeed, Uncanny, Daily Science Fiction, Apex Magazine, Escape Pod, Shimmer, Strange Horizon, Clarksworld, Giganotosaurus, Tor.com, Fireside Fiction, and Terraform. Escape Pod is slightly different since it includes science fiction in the form of audio. However, the texts could be read from the website.

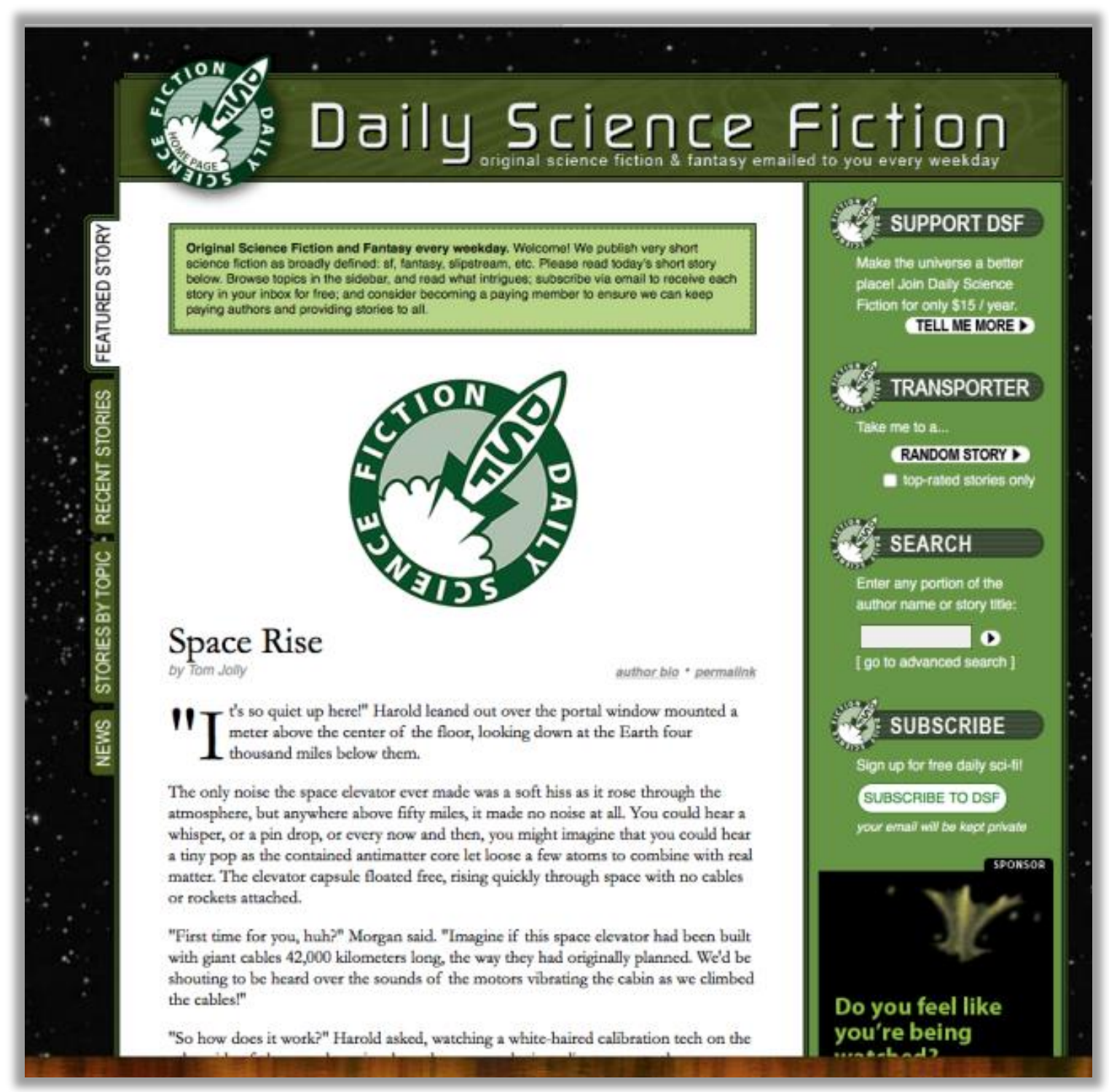

Figure 01. [Daily Science Fiction is one of the science fiction webistes] 


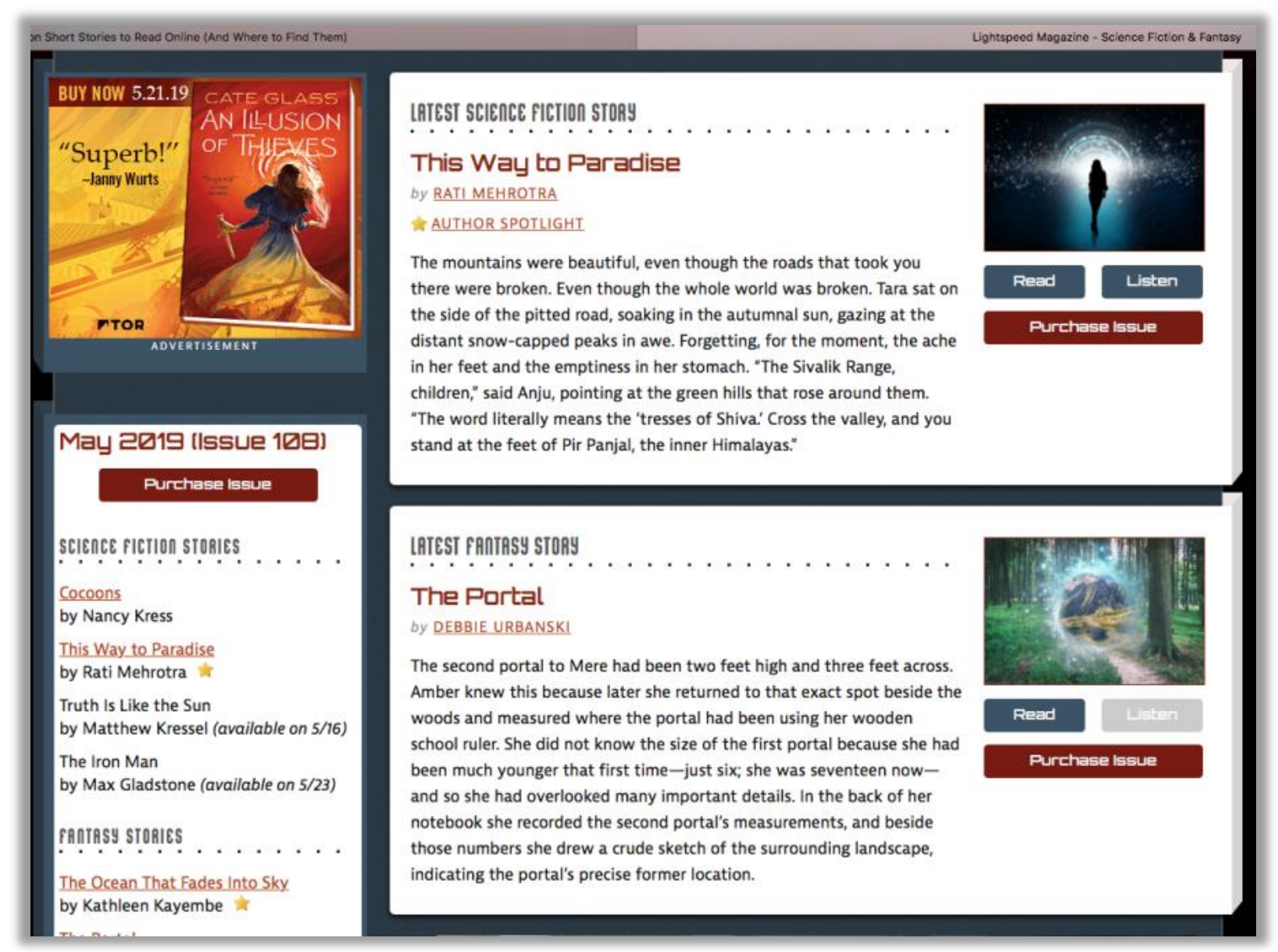

[Lightspeed Magazine allows readers to read science fiction stories]

\section{Science Fiction in Youtube}

Through Youtube, science fiction comes in many styles. Some of them are in the form of audio without visual which provide only audios. Readers or listeners are able to listen to science fiction stories through this space. One of the texts which are created in this form are Triplenetary by E.E Smith, and others are adapted from Starship Troopers novel by Robert A. Heinlein for 9 hours 54 minutes and 33 seconds which was viewed by 71007 viewers. In addition, another story that gains attention is Science Fiction Audio Books by Brian Stelly which includes Alien, Out of the Shadows by Tim Lebbon and others. Next, The Last Question by Isaac Asimov, 8 Short Sci-Fi Stories and various other audiobooks which are adapted from well-known authors such as H.G Wells, Arthur C. Clark, Jules Verne and many more. Other than in the form of audio, readers could watch short films based on science fiction via Youtube. Some the short film which can be watched are Anomaly dan Pulsar, Perfectly Natural, The Candidate, FTL and other publication by DUST, Stealing Time by Finitefilm and many more. Search made by using science fiction as keywords failed to locate Malay science fiction be it in the form of adaptations to audiobooks or short films. A few short films were produced for specific objective for instance Sekolah Zombi by Faiz Haikal TV, or to fulfill task requirement such as Filem Pendek Sci-Fi-Asid, INVI which was uploaded by Thewepics, HKB 319 Sains Fiksyen dan Media Baru (Where Am I), HKB 319: Zombiekolonial and others. 


\section{Science Fiction Through Application}

One issue that must be touched in discussing digital space is the application in smartphone, tablet or computer. From the research conducted, there are several applications which offer online reading such as Science Fiction Books, Science Fiction and Fantasy Stories dan Free Science Fiction. Search made for the term Sci-Fi, reveals most applications provide science fiction games such as Infinity Ops: Sci-Fi FPS, Sci-fi Futures, CyberSphere Sci-Fi Shooter, Sci-Fi Space VR and many more. One popular application that provides various texts including science fiction genre, is Wattpad. It is an application that enables readers to access science fiction texts, read as well as write and publish their own texts. Wattpad's main advantage is it is available in many languages including Bahasa Melayu (Bahasa Indonesia). To date, Wattpad becomes the platform that connects 70 million authors and readers. Malay science fiction texts which are listed in this application are Deja $V u$ by NurulAin Syuhada from Karyaseni2u platform, Liberosis/Audelia by Azalearml, Mikrofiksyen by Sheeraghafar and others.

\section{The Characteristics of New Media in Science Fiction}

Literary texts in the digital world have their own characteristics which differ from other conventional texts including those on the same genre. Since this research works on digital literary texts, cyber and new media characteristics must be analyzed. Upon investigation, it is challenging to locate a science fiction text which is created with cyber characteristics. Some relevant instances are Science Fiction Games, The Fall of Lazarus(2017) and Prominence. Prominence (2016) is the only science fiction which comes in the form of games. It has complete multimedia characteristics and suitable with the digital literary characteristics that come with narrative, related to multimedia elements, hypertext and hypermedia. Prominence brings the users through an adventure with first person character, exploring the game through point and clicks which are heavy with puzzles, interesting character combination, a story full of hope and humanity in the best science fiction tradition. The game presents attractive graphics in the form of HD, navigation and movement, Inventory and UI, puzzles, characters that come to alive in the form of graphic and readers could choose. Now, Prominence is also available as an e-book. The readers will be able to read through EPUB, $\mathrm{MOBI}$ and PDF formats. Through e-book, readers will experience different reading compared to games that offer 10 chapters with hypertext. These chapter can be read through the links provided. The only difference between e-book and games; through e-book, the readers are only provided with hypertext without interesting graphics or sounds. 


\section{इPRDMINENCE}

a science-fiction adventure game

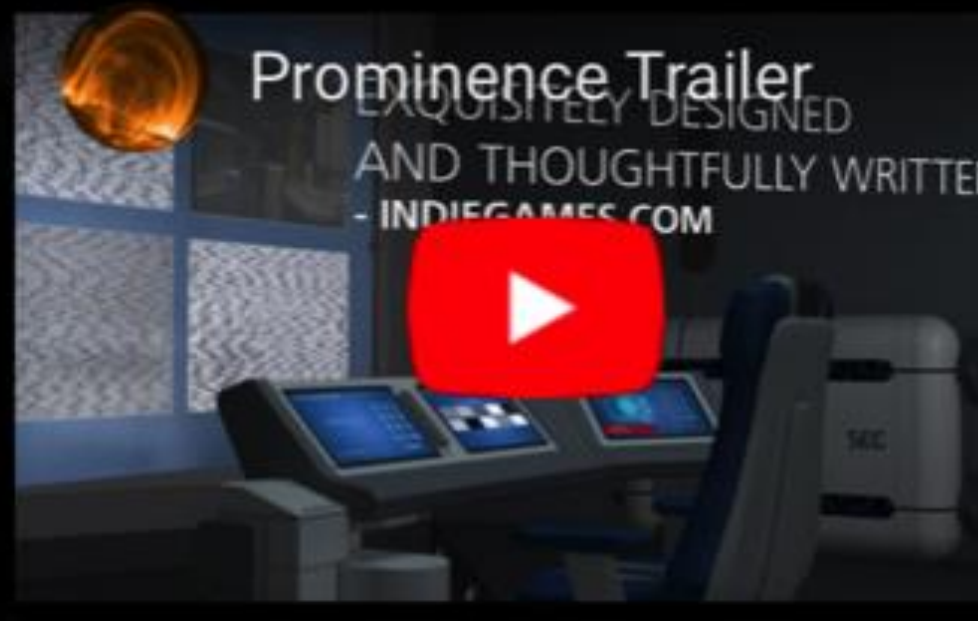

(Also available: features and gameplay preview.)
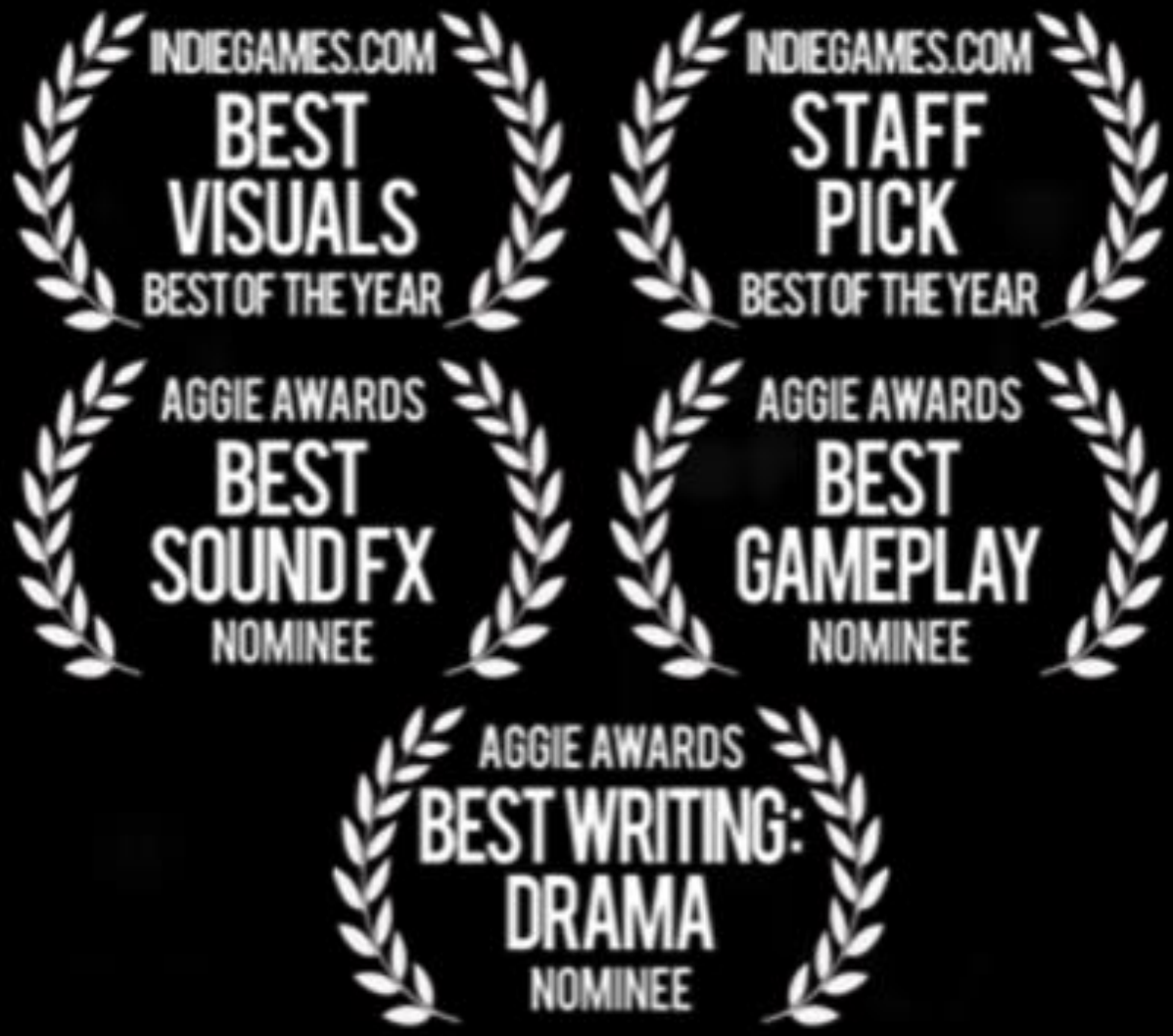

Figure 02. [Prominence is a science fiction adventure games available in cyber space] 


\section{Conclusion}

Science fiction texts in the digital world generally lacks implementation be it in terms on its text or production. This research is conducted to document science fiction texts which can be found online. Several websites provide users texts which could be read but these texts still come in the form of conventional texts which could be printed. If there is an implementation of cyber or multimedia elements, it is mostly in the form of games. Through this research, it is apparent that Malay science fiction is still left behind in terms of its form and content even though attempts to expand this genre is rather successful. Literature texts in digital media is needed since the world today depends on the latest technology as a type of innovation in the field of literature.

\section{Significant of the Research}

Studies in science fiction, particularly on its presence in Malay literature in digital form, is rather limited. Instead, many research applied existing theories on science fiction texts or films. Most of them focus on analysis of specific texts. However, this research aims to study the basis of science fiction in digital media, which is hardly explored by researchers, especially those in Malaysia. The findings will contribute to readers' knowledge in science fiction in digital form that are accessible on social media. Future researchers could refer to this study and apply suitable theories for to delve deeper in this issue.

\section{Acknowledgement}

Article based on Bridging Incentive Grant (Universiti Sains Malaysia) entitled "Fiksyen Sains dalam dunia digital, kajian terhadap teks dan visual" (304/PHUMANITI/6316557) lead by Dr. Rosnidar Ain, Universiti Sains Malaysia.

\section{References}

Aydin, E. D., Tong, T., Pusat S. E. (2006). The Effects of Futurisme on Science Fiction Cinema. Retrieved from http://www.irbnet.de/daten/iconda/06059010113.pdf.

Basset, C., Steinmuller, E., Vose, G. (2013). Better Made Up, The Mutual Influence of Science Fiction and Innovation. Retrieved from https://pdfs.semanticscholar.org/284c/9f26e287c95895727dddf9abfb05ed53eb5d.pd f.

Bassett, C., Steinmueller, E., Voss, G. (2013). Better Made Up: The Mutual Influence of Science Fiction and Innovation. Nesta Working Paper No. 13.7. Retrieved from https://media.nesta.org.uk/documents/better_made_up_the_mutual_influence_of_s cience_fiction_and_innovation.pdf

Birtchnell, T., \& Urry, J. (2013). 3D, SF and the Future. Retrieved from http://dx.doi.org/10.1016/j.futures.2013.03.005

Car, S. (2019). The Sinking of The Jade Rabbit. Retrieved from https://www.prismaticamagazine.com/literature/2019/8/8/the-sinking-of-the-jaderabbit?fbclid=IwAR2t7IDTzbmr7xj2xisG9-7yBxqrv5xxWIbScVi-KeZOHqQpvYarMUwwQY

Evnine, S. J. (2015). "But Is It Science Fiction?": Science Fiction and a Theory of Genre. Retrieved from https://philarchive.org/archive/EVNBII.

Thomas, H. (2011). Technology's Other Storytellers: Science Fiction as History of Technology. L.F. David \& G.S. Eric (Eds) North Carolina and London: McFarland and Company, Inc.

Telotte, J. P. (2008). 3D, SF, and the Future. Kentucky: The University Press of Kentucky. 
Kumari, G. M. P. (2013). Chapter 1, Introduction: Science Fiction and Literature.. Retrieved from https://shodhganga.inflibnet.ac.in/bitstream/10603/62113/7/07_chapter\%20\%20i.pdf

Prominence. (2010). A Science Fiction Adventure Game. Retrieved from http://www.irbnet.de/daten/iconda/06059010113.pdf

The Fall of Lazarus. (2007). Retrieved from https://thefalloflazarus.com.

Torras, C. (2020). Science-Fiction: A Mirror for the Future of Humankind. The Engaging Debate on Al and ethics Favoured by Science Fiction. Retrieved from https://revistaidees.cat/en/science-fiction-favors-engaging-debate-on-artificial-intelligenceand-ethics/ 